\title{
Biological activity of Cryptococcus neoformans and Cryptococcus gattii from clinical and environmental isolates
}

\author{
Atividade biológica de Cryptococcus neoformans $e$ Cryptococcus gattii \\ provenientes de isolados clínicos e ambientais
}

Antonio Marcio Barbosa Junior ${ }^{1}$; Bruno Fernandes de Oliveira Santos ${ }^{2}$; Erick de Oliveira Carvalho ${ }^{3}$;

Dângelly Lins Figuerôa Martins de Mélói ; Rita de Cássia Trindade'; Maria Aparecida de Resende Stoianoff ${ }^{6}$

\begin{abstract}
Introduction: Cryptococcus neoformans and Cryptococcus gattii are encapsulated basidiomycetous yeasts with worldwide distribution. They cause cryptococcosis with features of systemic infection, affecting the central nervous system, lungs and skin in humans and animals. These fungi present numerous virulence factors that allow them to invade the host and multiply, among which extracellular enzyme capacity and microbial adaptation to different temperatures are worth mentioning. Objective: To evaluate the production of protease and investigate possible differences in thermotolerance and urease activity in clinical and environmental yeast isolates. Material and methods: Culture methods and $\mathrm{Pz}$ analysis were applied to assess urease and protease, whereas the optical density method was used to analyze biological activity in thermotolerance. Results: There was no significant results as to microbial growth at the tested temperatures $\left(25^{\circ}, 37^{\circ}\right.$ and $42^{\circ} \mathrm{C}$ ). It was observed that clinical specimens grew better than environmental ones at elevated temperatures. As to $C$. neoformans, the moderate production of urease enzyme prevailed in both clinical and environmental isolates within $24 \mathrm{~h}$ or $48 \mathrm{~h}$. Moreover, there was significant production on the seventh day of reading. The best reading time for viewing protease production in both isolates and species was the seventh day: $96 \%$ clinical samples and $94 \%$ environmental isolates. Conclusion: Further studies are required in order to investigate the virulence factors of $C$. neoformans and $C$. gattii cerebrospinal isolates from patients with meningoencephalitis and environmental samples from Sergipe. Furthermore, a higher technical accuracy and statistical precision are indispensable.
\end{abstract}

Key words: Cryptococcus neoformans; fungal proteins; mycology; yeast; Cryptococcus gattii.

\section{INTRODUCIION}

Cryptococcus neoformans and Cryptococcus gattii are encapsulated basidiomycetous yeasts with worldwide distribution. They cause cryptococcosis with features of systemic infection, affecting the central nervous system, lungs and skin in humans and animals ${ }^{(13,18)}$. For several years, $C$. neoformans was regarded as a single species with some varieties. Currently, there are two species: C. neoformans with two varieties (var. grubii - serotype $\mathrm{A}$ and var. neoformans - serotype $\mathrm{D}$ ) and hybrid serotype $\mathrm{AD}$;
C. gattii (serotypes B and C) ${ }^{(14,18)}$. C. neoformans occurs mostly among immunocompromised individuals, mainly human immunodeficiency virus (HIV) patients.

Cryptococcosis is among the top three opportunistic infections in patients with acquired immunodeficiency syndrome (AIDS), causing morbidity and mortality in this population ${ }^{(17-19,25)}$.

Meningoencephalitis caused by $C$. neoformans occurs in $6 \%$ to $8 \%$ of patients with $\operatorname{AIDS}^{(6)}$. Cryptococcosis caused by $C$. gattii, unlike those caused by $C$. neoformans, occurs

First submission on 23/05/12; last submission on 31/12/12; accepted for publication on 14/03/13; published on 20/06/13

1. Doctor im Microbiology by Universidade Federal de Minas Gerais (UFMG); assistant professor at Universidade Federal de Sergipe (UFSE).

2. Resident in Neurology at Universidade Federal de São Paulo (UNIFESP).

3. Resident in Cardiology at Instituto Dante Pazzanese.

4. Doctor in Biotechnology by Rede Nordeste de Biotecnologia (RENORBI0); researcher at UFSE Applied Microbiology Laboratory.

5. Doctor in Microbiology by UFMG; associate professor and researcher at UFSE Applied Microbiology Laboratory.

6. Post-doctorate in Microbiology at UFMG; professor and researcher at UFMG Mycology Laboratory. 
mainly among healthy hosts and it is classically described as a tropical disease. Nevertheless, there was an outbreak of C. gattii on Vancouver Island, a temperate climate region, which suggests that $C$. gattii is not exclusively restricted to tropical and subtropical areas ${ }^{(13,20)}$. Cryptococcus gattii is endemic in the north and northeast regions of Brazil. It affects mostly children and young adults ${ }^{(25)}$. Despite the fact that cryptococcosis is a systemic infection that affects mostly HIV patients, there are few studies on molecular epidemiology and clinical aspects, mainly in the northeast region of Brazil ${ }^{(8)}$. Cryptococcal meningitis arises in $8 \%$ to $30 \%$ of AIDS patients and the mortality is high in $6 \%$ to $29 \%$ of the cases $^{(22)}$.

C. neoformans has been isolated from bird excrements, plant debris and contaminated soil ${ }^{(5)}$. It has also been found in plants such as Eucalyptus ${ }^{(9)}$, Brazilian native plants ${ }^{(15)}$ and armadillo burrows in the northeast of Brazil ${ }^{(10,15,16)}$. C. gattii has been continuously isolated from Eucaliptus spp., ${ }^{(1,9)}$. It has also been isolated from Amazonian native plants ${ }^{(1,10)}$. Moreover, it has been found in animals from temperate regions such as dolphins (Tursiops truncatus) in the Atlantic ocean (Metropolitan region of Vancouver, Canada) ${ }^{(23)}$. In this specific case, there was an epidemic affecting both immunocompetent and immunodeficient patients as well as animals (dogs and dolphins) ${ }^{(20,23)}$. Additionally, strains of this pathogenic yeast were found in plant species from Canada ${ }^{(23)}$. This species was also found in wasps, bats, koalas, and camels ${ }^{(9,15,16)}$. Both species are commonly isolated in hen excrements as well as deteriorating wood planks and trunks from living trees ${ }^{(15,16)}$

Several factors are involved in the adherence process, destruction and invasion of host tissues. According to the literature, protease production, which ascertains a potential adaptability to adverse environments, is among them. In general, proteinases degrade several human proteins such as albumin, hemoglobin, keratin and immunoglobulin A (IgA), which are present in different sites. This proteolytic activity has been associated with tissue invasion and it is considered a virulence factor ${ }^{(14)}$.

These fungi have several virulence factors that allow invasion of the host and their multiplication ${ }^{(24)}$. The present study evaluated protease production by Cryptococcus neoformans and Cryptococcus gattii and possible differences in enzymatic activity between clinical and environmental samples. Furthermore, it verified possible differences in thermotolerance and urease activity in clinical and environmental samples in order to confirm, albeit indirectly, these features as virulence factors.

\section{OBJECTIVE}

To observe the capacity of extracellular enzyme production (urease and proteinase) and biological activity in several temperatures (thermotolerance) in clinical and environmental isolates of Cryptococcus neoformans and Cryptococcus gattii from Sergipe, Brazil.

\section{MATERIAL AND METHODS}

\section{Preparation of microbial strains}

70 strains were selected from the collection of the Applied Microbiology Laboratory - Universidade Federal de Sergipe (AMLUFS), including 35 environmental isolates, 35 clinical isolates and two standard strains (ATCC 32608 and ATCC 56990). In the strain description, we analyzed 9 strains of Cryptococcus gattii and 26 strains of Cryptococcus neoformans from cerebrospinal samples collected from patients with meningoencephalitis and assisted at Sergipe Emergency Hospital.

The surveyed pathogenic yeasts were isolated from several environmental samples from Sergipe, including 34 strains of Cryptococcus neoformans and 1 strain of Cryptococcus gattii. The environmental substrates were from bird and bat excrements as well as native and exotic tree trunks from Sergipe. The strains were inoculated in Sabouraud Dextrose and incubated at $25^{\circ} \mathrm{C}$ for five days.

\section{Ability to grow in thermotolerance}

Five tubes/sample were employed for thermotolerance analysis. We inoculated $5 \mu \mathrm{l}$ of suspension with $1.2 \times 10^{9}$ microorganisms $/ \mathrm{ml}$ in each tube, which contained $3 \mathrm{ml}$ of Sabouraud broth. Each tube was incubated at different temperatures $\left(25^{\circ} \mathrm{C}, 30^{\circ} \mathrm{C}, 37^{\circ} \mathrm{C}\right.$, $40^{\circ} \mathrm{C}$ and $42^{\circ} \mathrm{C}$ ). Turbidity readings were carried out through MacFarland standard and spectrophotometer within 24 hours, 48 hours and seven-day incubation periods ${ }^{(4)}$.

\section{Enzymatic activity: urease}

For the assessment of urease activity, we employed Christensen agar (with Ph adjusted to 5.0) added to a $20 \%$ urea solution, distributed into slanted tubes ( $3 \mathrm{ml} /$ tube). After inoculation, the samples were incubated at $25^{\circ} \mathrm{C}$ and the readings were performed after 24 hours, 48 hours and seven days. The results were interpreted according to the following criteria: negative (medium 
remained yellow), moderate activity (half of the medium became pink) and intense activity (the medium became entirely pink) ${ }^{(2)}$.

\section{Enzymatic activity: protease}

We applied plates with protease agar containing fraction $\mathrm{V}$ bovine albumin and Protovit, in which $5 \mu$ of suspension with $1.2 \times 10^{9}$ microorganisms $/ \mathrm{ml}$ were inoculated in duplicate. The inoculated plates were incubated at $37^{\circ} \mathrm{C}$ and the reading was conducted after seven days. Light areas around the colonies were interpreted as albumin degradation. The colonies (a) and the colonies plus light halo (b) were assessed. Protease activity was estimated through $\mathrm{Pz}$ calculation (a/b) so that the lower $\mathrm{Pz}$, the higher the enzymatic activity. As positive controls, we used six endocervical samples of Candida spp. from AML-UFS strain database $^{(3)}$.

\section{Statistical analysis of yielded data}

All strains were statiscally analyzed through SPSS v. 11 and BioEstat v.5 software. They were also submitted to mean test and comparison between variables through student's $t$ - distribution (thermotolerance and protease) and ANOVA variance analysis (urease). Turkey test was performed after significant $p<0.01$ for statistical data differentiation.

\section{RESULTS}

Table 1 shows the microbial concentration of Cryptococcus neoformans special complex in isolates from Sergipe, northeast of Brazil, when tested at different temperatures in order to assess thermotolerance.

Table 2 shows the optical density of clinical isolates of both surveyed yeasts (C. neoformans and $C$. gattii) for the analysis of growth under thermotolerance biological activity.

Table 3 demonstrates the mean concentrations of $C$. neoformans in environmental samples at the seventh day of incubation reading after carrying out thermotolerance experiments under the following temperatures: $25^{\circ} \mathrm{C}, 30^{\circ} \mathrm{C}, 37^{\circ} \mathrm{C}$, $40^{\circ} \mathrm{C}$ and $42^{\circ} \mathrm{C}$.

According to Table 4, when we analyze thermotolerance in environmental isolates, it is observable the diminishment in optical density in comparison with clinical isolates, though with no statistical difference when $p<0.01$.

TABLE 1 - Mean microorganism concentrations in the seventh day of thermotolerance reading and correlation of tested temperatures and strain origins

\begin{tabular}{cccccc}
\hline & $25^{\circ} \mathrm{C}$ & $30^{\circ} \mathrm{C}$ & $37^{\circ} \mathrm{C}$ & $40^{\circ} \mathrm{C}$ & $42^{\circ} \mathrm{C}$ \\
\hline Clinical (35) & $9.5 \times 10^{8}$ & $15.5 \times 10^{8}$ & $7.4 \times 10^{8}$ & $3.7 \times 10^{8}$ & $7.6 \times 10^{8}$ \\
environmental (35) & $9 \times 10^{8}$ & $11.5 \times 10^{8}$ & $9.7 \times 10^{8}$ & $4.6 \times 10^{8}$ & $3.1 \times 10^{8}$ \\
$p$ value (t-test) & 0.574 & $0.012^{*}$ & 0.368 & 0.698 & $0.040^{*}$ \\
\hline
\end{tabular}

* There was statistical difference when $\mathrm{t}$ Test was conducted $(\mathrm{p}<0.01)$.

TABLE 2 - Mean microorganism concentrations in the seventh day of thermotolerance reading with only clinical samples

\begin{tabular}{cccccc}
\hline & $25^{\circ} \mathrm{C}$ & $30^{\circ} \mathrm{C}$ & $37^{\circ} \mathrm{C}$ & $40^{\circ} \mathrm{C}$ & $42^{\circ} \mathrm{C}$ \\
\hline Clinical/C. neoformans (26) & $8.5 \times 10^{8}$ & $12.5 \times 10^{8}$ & $9.7 \times 10^{8}$ & $2.9 \times 10^{8}$ & $6.3 \times 10^{8}$ \\
Clinical/C.gattii (9) & $7 \times 10^{8}$ & $8.5 \times 10^{8}$ & $8.8 \times 10^{8}$ & $2.6 \times 10^{8}$ & $3.4 \times 10^{8}$ \\
$p$ value (t-test) & 0.574 & $0.012^{*}$ & 0.368 & 0.698 & $0.040^{*}$ \\
\hline
\end{tabular}

* There was statistical difference when $\mathrm{t}$ Test was conducted $(\mathrm{p}<0.01)$

TABLE 3 - Mean microorganism concentrations in the seventh day of thermotolerance reading with only environmental samples

\begin{tabular}{cccccc}
\hline & $25^{\circ} \mathrm{C}$ & $30^{\circ} \mathrm{C}$ & $37^{\circ} \mathrm{C}$ & $40^{\circ} \mathrm{C}$ & $42^{\circ} \mathrm{C}$ \\
\hline $\begin{array}{c}\text { Environmental/ } \\
\text { C. neoformans (34) } \\
\text { Environmental/ } \\
\text { C.gattii (1) }\end{array}$ & $7.5 \times 10^{8}$ & $9.5 \times 10^{8}$ & $7.9 \times 10^{8}$ & $2.7 \times 10^{8}$ & $7.9 \times 10^{8}$ \\
$p$ value (t-test) & $7 \times 10^{8}$ & $6.7 \times 10^{8}$ & $6.7 \times 10^{8}$ & $1.6 \times 10^{8}$ & $3.4 \times 10^{8}$ \\
& 0.574 & $0.012^{*}$ & & & 0.698 \\
\hline
\end{tabular}

* There was statistical difference when $\mathrm{t}$ Test was conducted $(\mathrm{p}<0.01)$. 
Table 5 shows statistical studies on optical density and comparison of surveyed temperatures in C. neoformans isolates from both clinical and environmental sites.

Table 5 corroborates data shown in Table 4.

Table 6 presents the profile of urease production in 70 surveyed pathogenic yeasts by comparing both environmental and clinical isolated sites.

Table 7 indicates $C$. neoformans urease production in both environmental and clinical isolates after 24 hours, 48 hours and seven days.

TABLE 4 - Statistical correlation between mean concentration of Cryptococcus neoformans isolates under thermotolerance and differences in test temperatures

\begin{tabular}{cccc}
\hline & $25^{\circ} \mathrm{C} \times 37^{\circ} \mathrm{C}$ & $25^{\circ} \mathrm{C} \times 42^{\circ} \mathrm{C}$ & $37^{\circ} \mathrm{C} \times 42^{\circ} \mathrm{C}$ \\
\hline $\begin{array}{c}\text { Clinical/ } \\
\text { C. neoformans (26) } \\
\text { Environmental/ }\end{array}$ & 0.069 & 0.152 & 0.882 \\
$\begin{array}{c}\text { C. neoformans (34) } \\
\text { p value (t-test) }\end{array}$ & 0.717 & $0.0^{*}$ & $0.005^{*}$ \\
* There was statistical difference when $\mathrm{t}$ Test was conducted ( $\mathrm{p}<0.01)$.
\end{tabular}

Table 8 shows urease enzymatic production in C. gattii strains in both environmental and clinical isolates.

Table 9 demonstrates protease production in Cryptococcus neoformans and Cryptococcus gattii in both environmental and clinical isolates from the collection of UFS/AML.

Table 10 shows protease enzymatic activity of $C$. neoformans from both clinical and environmental sites after 24 hours, 48 hours and seven days.

Table 11 shows data on protease production in C. gattii strains from both environmental and clinical isolates after 24 hours, 48 hours and seven days.

TABLE 5 - Statistical correlation between mean concentration of Cryptococcus gattii isolates under thermotolerance and the differences in test temperatures

\begin{tabular}{cccc}
\hline & $25^{\circ} \mathrm{C} \times 37^{\circ} \mathrm{C}$ & $25^{\circ} \mathrm{C} \times 42^{\circ} \mathrm{C}$ & $37^{\circ} \mathrm{C} \times 42^{\circ} \mathrm{C}$ \\
\hline Clinical/C. gattii (9) & 0.032 & 0.121 & 0.701 \\
Environmental/C. & 0.68 & $0.015^{*}$ & $0.015^{*}$ \\
$\quad$ gattii (34) & & & \\
p value (t-test) & 0.689 & $0.018^{*}$ & $0.020^{*}$ \\
\hline * There was statistical difference when $\mathrm{t}$ Test was conducted $(\mathrm{p}<0.01)$.
\end{tabular}

TABLE 6 - Urease production activity in clinical and environmental Cryptococcus neoformans and Cryptococcus gattii samples isolated in Sergipe, Brazil

\begin{tabular}{cccccccccc}
\hline & \multicolumn{3}{c}{ 24 hours } & & 48 hours & & \multicolumn{2}{c}{7 th day } \\
\hline & Negative & Moderate & Intense & Negative & Moderate & Intense & Negative & Moderate & Intense \\
\hline Clinical (35) & $0^{\mathrm{a}}$ & $35^{\mathrm{b}}$ & 0 & $0^{\mathrm{a}}$ & $35^{\mathrm{a}}$ & 0 & 0 & $1^{\mathrm{a}}$ & $34^{\mathrm{b}}$ \\
Environmental (35) & $1^{\mathrm{a}}$ & $32^{\mathrm{b}}$ & $2^{\mathrm{c}}$ & $1^{\mathrm{a}}$ & $32^{\mathrm{b}}$ & $2^{\mathrm{c}}$ & $1^{\mathrm{a}}$ & $2^{\mathrm{b}}$ & $1^{\mathrm{a}}$ \\
ATCC 32608 & 0 & 1 & 0 & 0 & 1 & 0 & 0 & 0 & 1 \\
ATCC 569900 & 0 & 1 & 0 & 0 & 1 & 0 & 0 & 0 & 1 \\
Total & 1 & 69 & 2 & 1 & 69 & 2 & 1 & 3 & 68 \\
\hline
\end{tabular}

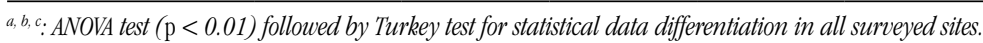
ANOVA: variance analysis.

TABLE 7 - Urease production activity in clinical and environmental Cryptococcus neoformans samples isolated in Sergipe, Brazil

\begin{tabular}{cccccccccc}
\hline & & & & 48 hours & & \multicolumn{2}{c}{7 th day } \\
\hline & Negative & Moderate & Intense & Negative & Moderate & Intense & Negative & Moderate & Intense \\
\hline Clinical (26) & 0 & $26^{\mathrm{a}}$ & 0 & 0 & $26^{\mathrm{a}}$ & 0 & 0 & 0 & $26^{\mathrm{a}}$ \\
Environmental (34) & $1^{\mathrm{a}}$ & $31^{\mathrm{b}}$ & $2^{\mathrm{c}}$ & $1^{\mathrm{a}}$ & $31^{\mathrm{b}}$ & $2^{\mathrm{c}}$ & $1^{\mathrm{a}}$ & $2^{\mathrm{b}}$ & $31^{\mathrm{c}}$ \\
Total & 1 & 57 & 2 & 1 & 57 & 2 & 1 & 28 & 65 \\
\hline
\end{tabular}

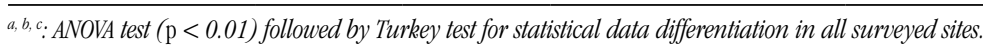

ANOVA: variance analysis. 
TABLE 8 - Urease production activity in clinical and environmental Cryptococcus gattii samples isolated in Sergipe, Brazil

\begin{tabular}{cccccccccc}
\hline & & 24 hours & & & 48 hours & & \multicolumn{2}{c}{ 7th day } \\
\hline & Negative & Moderate & Intense & Negative & Moderate & Intense & Negative & Moderate & Intense \\
\hline Clinical (9) & 0 & $9^{\mathrm{a}}$ & 0 & 0 & $9^{\mathrm{a}}$ & 0 & 0 & $1^{\mathrm{a}}$ & $8^{\mathrm{b}}$ \\
Environmental (1) & 0 & 1 & 0 & 0 & 1 & 0 & 0 & 0 & 1 \\
Total & 1 & 57 & 2 & 1 & 57 & 2 & 1 & 28 & 65 \\
\hline
\end{tabular}

a,b: ANOVA test $(\mathrm{p}<0.01)$ followed by Turkey test for statistical data differentiation in all surveyed sites. ANOVA: variance analysis.

TABLE 9 - Protease production activity in clinical and environmental Cryptococcus neoformans and Cryptococcus gattii samples isolated in Sergipe, Brazil

\begin{tabular}{ccccccc}
\hline & \multicolumn{2}{c}{24 hours } & & \multicolumn{2}{c}{ 48 hours } & \multicolumn{2}{c}{ th day } \\
\hline & Negative & Intense & Negative & Intense & Negative & Intense \\
\hline Clinical (35) & $34^{\mathrm{a}}$ & $1^{\mathrm{b}}$ & $12^{\mathrm{a}}$ & $23^{\mathrm{b}}$ & $1^{\mathrm{a}}$ & $34^{\mathrm{b}}$ \\
Environmental (35) & $35^{\mathrm{a}}$ & 0 & $4^{\mathrm{a}}$ & $31^{\mathrm{b}}$ & $2^{\mathrm{a}}$ & $33^{\mathrm{b}}$ \\
ATCC 32608 & 0 & 1 & 0 & 1 & 0 & 1 \\
ATCC 56990 & 1 & 0 & 1 & 0 & 1 & 0 \\
Total & 70 & 2 & 17 & 55 & 4 & 68 \\
\hline
\end{tabular}

$\overline{a, b}:$ ANOVA test $(\mathrm{p}<0.01)$ followed by Turkey test for statistical data differentiation in all surveyed sites. ANOVA: variance analysis.

TABLE 10 - Protease production activity in clinical and environmental Cryptococcus neoformans samples isolated in Sergipe, Brazil

\begin{tabular}{ccccccc}
\hline & \multicolumn{2}{c}{24 hours } & \multicolumn{2}{c}{ 48 hours } & \multicolumn{2}{c}{7 th day } \\
\hline & Negative & Intense & Negative & Intense & Negative & Intense \\
\hline Clinical (26) & $26^{\mathrm{a}}$ & 0 & $8^{\mathrm{a}}$ & $18^{\mathrm{b}}$ & $1^{\mathrm{a}}$ & $25^{\mathrm{b}}$ \\
Environmental (34) & $34^{\mathrm{a}}$ & 0 & $4^{\mathrm{a}}$ & $30^{\mathrm{b}}$ & $2^{\mathrm{a}}$ & $32^{\mathrm{b}}$ \\
Total & 60 & 0 & 12 & 48 & 3 & 57 \\
\hline
\end{tabular}

$\overline{a, b}:$ ANOVA test $(\mathrm{p}<0.01)$ followed by Turkey test for statistical data differentiation in all surveyed sites. ANOVA: variance analysis.

TABLE 11 - Protease production activity in clinical and environmental Cryptococcus gattii samples isolated in Sergipe, Brazil

\begin{tabular}{ccccccc}
\hline & \multicolumn{2}{c}{24 hours } & \multicolumn{2}{c}{ 48 hours } & \multicolumn{2}{c}{ 7th day } \\
\hline & Negative & Intense & Negative & Intense & Negative & Intense \\
\hline Clinical (9) & $8^{\mathrm{a}}$ & $1^{\mathrm{b}}$ & $4^{\mathrm{a}}$ & $5^{\mathrm{a}}$ & 0 & 9 \\
Environmental (1) & 1 & 0 & 0 & 1 & 0 & 1 \\
Total & 9 & 1 & 4 & 6 & 0 & 10 \\
\hline
\end{tabular}

a,b: ANOVA test $(\mathrm{p}<0.01)$ followed by Turkey test for statistical data differentiation in all surveyed sites. ANOVA: variance analysis.

\section{DISCUSSION}

There was statistical difference between environmental and clinical isolates when $p<0.01$, regardless of the yeast species tested at $30^{\circ} \mathrm{C}$ and $42^{\circ} \mathrm{C}$. There was statistical uniformity in optical density for other temperatures. It is particularly worth mentioning that in terms of fungal growth there was no statistical difference between environmental and clinical isolates and the strains (70) when surveyed at body temperature $\left(37^{\circ} \mathrm{C}\right)$.

The most significant increase in the descriptive data on both clinical and environmental isolates occurred at the following 
temperatures: $42^{\circ} \mathrm{C}, 40^{\circ} \mathrm{C}, 37^{\circ} \mathrm{C}, 30^{\circ} \mathrm{C}$ and $25^{\circ} \mathrm{C}$. It is important to highlight that the typical average temperature of the studied region is $30^{\circ} \mathrm{C}$.

It was observed that there was statistical difference in both species at $30^{\circ} \mathrm{C}$ and $42^{\circ} \mathrm{C}$. There was no statistical difference in the other temperatures. There was growth in $C$. neoformans and $C$. gattii clinical isolates at $30^{\circ} \mathrm{C}$ and $37^{\circ} \mathrm{C}$, as shown in Table 1 . The worst thermotolerance and optical density relation was $40^{\circ} \mathrm{C}$ temperature.

As it was mentioned in the previous tables, there was statistical difference at $30^{\circ} \mathrm{C}$ and $42^{\circ} \mathrm{C}$ in comparison with other temperatures. In these pathogenic yeasts isolated from environmental sites in the state of Sergipe, the highest optical density for $C$. neoformans was at the following temperatures: $37^{\circ} \mathrm{C}$ and $30^{\circ} \mathrm{C}$. On the other hand, C. gattii showed higher optical density for clinical isolates at $30^{\circ} \mathrm{C}$ and $37^{\circ} \mathrm{C}$ and for environmental isolates at $25^{\circ} \mathrm{C}, 30^{\circ} \mathrm{C}$ and $37^{\circ} \mathrm{C}$.

There was statistical difference in the optical density of this yeast when we compared the following temperatures: $25^{\circ} \mathrm{C}$ and $37^{\circ} \mathrm{C}$ with $42^{\circ} \mathrm{C}$. There was no statistical difference for the other temperatures. It may be inferred that it is difficult to obtain reference optical density for thermotolerance test at $42^{\circ} \mathrm{C}$, that is to say that there is fungal growth inhibition, mainly when this temperature is required in order to obtain bioproducts and/or bioprocesses relevant to the health area.

By confronting data on $C$. gattii, though $p$ values were more significant, there was no homogeneity in the statistical analysis of optical density and thermotolerance.

As to thermotolerance, when mean microorganism concentrations from clinical and environmental samples were compared at different temperatures and after seven days, there was significant statistical difference at $30^{\circ} \mathrm{C}(\phi<0.05)$ and $42^{\circ} \mathrm{C}$ $(p<0.05)$. There was no difference at other temperatures (Tables 2 and 3). By using $t$ test, it was observed that there was no significant statistical difference in the comparison of mean microorganism concentrations from clinical samples at different temperatures, contrasting with environmental samples, in which there was significant statistical difference in the following comparisons: $25^{\circ} \mathrm{C} v$ s. $42^{\circ} \mathrm{C}(p<0.001)$ and $37^{\circ} \mathrm{C} v$ s. $42^{\circ} \mathrm{C}(p<0.001)$.

The use of microbial growth in several temperatures, mainly in the occurrence of circulating strains, specially in the northeast of Brazil and in plant and animal samples, provides information on the epidemiological aspects of these yeasts (virulence factors) as well as their ecology (biological activity). However, there was no significant result as to microbial growth neither at the tested temperatures $\left(25^{\circ} \mathrm{C}\right.$, $37^{\circ} \mathrm{C}$ and $42^{\circ} \mathrm{C}$ ) nor at the contrasted ones. In high temperatures $\left(30^{\circ} \mathrm{C}\right.$ and $\left.42^{\circ} \mathrm{C}\right)$, the clinical samples presented a higher growth with statistical significance in comparison with environmental ones. Moreover, the clinical samples grew regardless of the incubation temperature, which did not occur with environmental ones.

Casadevall et al. claim that thermotolerance $\left(\right.$ at $37^{\circ} \mathrm{C}$ ) is a singular phenomenon in the triggering of systemic mycoses. Therefore, the yeast with this featured virulence factor maximizes the triggering of this disease in humans. Zuyderduyn $e t$ al. state that, as far as thermotolerance is concerned, there are several genes involved in the pathogenesis of these fungi. By use of serial analysis of gene expression, the following genes were present: translation elongation factor 1, cyclophilin A, thioredoxin peroxidase, histone H4, ribosomal proteins 40S RPS12 60S RPL21A. The studied strain was $C$. neoformans $\mathrm{H} 99^{(26)}$.

In the analysis of urease production, there was statistical difference in the adopted temperatures for the analysis of enzymatic production (24 hours, 48 hours and seven days) in both clinical and environmental isolates. In the clinical isolates, there was statistical prevalence of moderate production within 24 and 48 hours. All isolates produced it (100\%). After the seventh day of enzymatic analysis, only the clinical strain remained with moderate production whereas the other 34 strains produced urease intensely. There were statistical differences among these data.

As to environmental samples, there was prevalence of moderate urease production in the following readings: 24 and 48 hours. 32 from the total of 35 surveyed strains produced it moderately, one did not produce it and two produced it intensely. There were statistical differences in all cases. In the seventh day of reading, 32 from the total 35 strains showed intense production, two revealed moderate production and one did not produce urease. It is worth highlighting that there were statistical differences within yielded data.

As to clinical samples, it was possible to notice that both 24 and 48- hours periods yielded a moderate production of urease (100\% of strains). In the seventh day of reading, eight from nine strains produced the enzyme intensely whereas one isolate revealed moderate production. In these cases, there were statistical differences when ANOVA test was adopted $(p<0.01)$ followed by Turkey test. The only strain of $C$. gattii isolated from environmental substrate in the state of Sergipe produced the enzyme moderately within both periods (24 and 48 hours). In the seventh day, there was an intense production of this enzyme, corroborating other yielded data.

Ato urease production, there were statistical differences when we compared data from 24 and 48- hours reading periods with the seventh day of data analysis. The moderate enzymatic production prevailed in C. neoformans environmental isolates within both 24 and 48- hours periods. In the seventh day, these strains progressed to intense production of urease. Analyzing the 
data from environmental isolates, there was also uniformity in the enzymatic production within 24 and 48- hours periods. 31 from 34 surveyed strains produced the enzyme moderately, one strain did not produce it and two produced it intensely. In the seventh day of reading, there was intense enzymatic production in 31 from the total of 34 surveyed strains and one of them did not produce any enzyme. There were statistical differences in these data. Therefore, it may be inferred that $C$. neoformans yields better results for urease in the seventh day of stimulus for enzymatic production.

Urease is an enzyme from the microbial metabolism that plays a major role as a virulence factor of several pathogenic agents such as

Cryptococcus neoformans and Cryptococcus gattii ${ }^{(3,4,24)}$. Urease hydrolyses urea in ammonia and carbamate, resulting in local $\mathrm{pH}$ increase, which may be applied in microbial identification as a result from colorimetric changes. Most C. neoformans clinical isolates are positive for urease ${ }^{(2)}$. Perfect et al. ${ }^{(21)}$ verified that $C$. neoformans strains that were negative for urease through the inactivation of the gene responsible for the enzymatic production had lower pathogenicity in comparison with the wild mutant reconstituted type, which was demonstrated by the survival of the sample after inoculation.

By use of ANOVA test, it was possible to notice that there was a significantstatistical difference between clinical and environmental samples. As to urease activity, all types of samples hydrolyzed urea fast, regardless of its type (clinical or environmental).

Torres-Rodríguez et $a l^{\left({ }^{(12)}\right.}$ report that there are several variables influencing this virulence factor, namely microbial biomass used in the experiment and test accuracy. In the same investigation, they demonstrated that Cryptococcus neoformans had a higher enzymatic activity or urease production in comparison with Cryptococcus gattii, which was not corroborated in the present study. Hsueh et al. ${ }^{(11)}$ reported the occurrence of moderate urease activity (37.5\%) in C. neoformans special complex isolates from Taiwan after 48 hours and low activity in urease production (62.5\%). These data differ from our present findings. Thus, the strains from this investigation presented potential urease production, which causes higher pathogenicity.

Other virulence factors involved in Cryptococcus neoformans and Cryptococcus gattii pathogenicity are the following enzymes: lipases, proteinases and proteases. They are involved in the destruction of cellular structures in order to offer nutrients to the pathogenic fungi and facilitate their systemic propagation ${ }^{(7)}$.

Casadevall et al. ${ }^{(3)}$ showed that proteinase is able to degrade proteins from the host, namely collagen, elastin, fibrinogen, immunoglobulins and proteins from the complement system. Furthermore, the authors highlighted that this host protein degradation may protect $C$. neoformans from the immune system by blocking phagocytosis.

In the data analysis based on proteinase production by encapsulated pathogenic yeasts, the reading time for the visualization of this enzyme in both sites (clinical and environmental) was 48 hours. For the clinical strains, 34 strains did not produce proteinase and one did within 24 hours whereas 12 strains did not produce proteinase and 23 did within 48 hours. In the seventh day of enzymatic reading, only one strain remained without producing the enzyme, whereas 34 strains did. It is particularly worth mentioning that there were statistical differences with result selection $(p<0.01)$ in all data and studied periods.

As to environmental samples, $100 \%$ of them showed no enzymatic production within 24 hours. 31 from 35 strains showed enzymatic production and only four strains showed none within 48 hours. In the seventh day of analysis, two from the total of four isolates that did not produce any reading within 48 hours remained without synthesizing the enzyme. In the last period, 33 strains produced proteinase. Standard Cryptococcus neoformans (ATCC 32608) and Cryptococcus gattii (ATCC56990) strains were used for test standardization. Standard ATCC32608 showed enzyme production in all surveyed periods whereas ATCC 56990 strains did not synthesize the enzyme during the experiment.

$100 \%$ of the strains did not produce the enzyme in neither of the sites within 24 hours. 18 clinical samples produced proteinase and eight did not synthesize it within 48 hours. As to environmental samples, 30 from 34 surveyed samples produced the enzyme. In the seventh day of biological reading, only one clinical sample and two environmental samples did not produce it. During this period, there was enzyme production in 25 clinical and 32 environmental samples. In the analyzed periods, there was statistical difference with data selection at $p<0.01$.

In the clinical $C$. gattii samples, eight from nine strains did not produce proteinase and one did within 24 hours. There was no statistical difference when we analyzed the production or absence of proteinase within 48 hours. Four from nine strains remained without producing whereas five did. In the studies on C. gattii virulence factors, the number of isolates was lower, which also influenced statistical analysis of experimental data. In the seventh day, $100 \%$ of clinical C. gattii synthesized proteinase. The only environmental $C$. gatti sample that produced proteinase was within 48 hours.

As to proteinase production, when $\mathrm{Pz}$ values from clinical and environmental samples were compared through ANOVA test, there was 
significant statistical difference $(\phi=0.66)$. Souza et al. ${ }^{(24)}$ report that isolates from Amazonas showed a high protease production $(\mathrm{Pz}<$ 0.64) with mean $\mathrm{Pz}=0.3$ for both Cryptococcus species, supporting the information found herein and implying the great potential in the production of this virulence factor in the studied pathogenic yeasts.

New studies with higher technical accuracy and precise data analysis are required to assess the virulence factors and biological activity of these encapsulated pathogenic yeasts from cerebrospinal samples collected from patients with meningoencephalitis attended at Sergipe Emergency Hospital as well as strains from several environmental sites (bird and pigeon excrements, guano, hen coops and native exotic tree hollows) from different areas in Sergipe. The collection of microorganism cultures, implementation of new technologies, establishment of partnerships and studies on microbial biodiversity point towards new directions and objectives in the epidemiological and ecological analysis of these yeasts as well as their endemic behavior in the northeast of Brazil.

\section{ACKNOWLEDGMENTS}

To the National Council for Scientific and Technological Development (CNPq), the Ministry of Science and Technology (MST), the Foundation for Supporting Research and Technology Innovation of the state of Sergipe (FAPITEC-SE), the State Secretariat for Economic Development, Science, technology and Tourism and the Government of the State of Sergipe for funding this scientific article.

To the Foundation and Institute Parreiras Horta (FIPH) and the Public Health Laboratory of the State of Sergipe (LACEN-SE) for kindly providing the clinical isolates collected over a ten-year collection from the AML-UFS.

\section{RESUMO}

Introdução: Cryptococcus neoformans e Cryptococcus gattii são leveduras encapsuladas basidiomicéticas com distribuição mundial. Causam criptococose com características de infecção sistêmica, afetando o sistema nervoso central, pulmão e pele em bumanos e animais. Esses fungos possuem inúmeros fatores de virulência que permitem invadir o bospedeiro e se multiplicar, entre eles destacam-se a capacidade enzimática extracelular e a adaptação microbiana a diversas temperaturas. Objetivo: Avaliar a produção de proteinase por essas leveduras, de isolados clinicos e ambientais, além de verificar possíveis diferenças na termotolerância e na atividade da urease. Material e métodos: Para urease e proteinase, foi utilizado o sistema de cultivo e análise Pz. Já para atividade biológica em termotolerância, foi analisado o método de densidade óptica. Resultados: Não há resultado significativo no crescimento, mesmo nas temperaturas testadas $\left(25^{\circ}, 37^{\circ} \mathrm{e} 42^{\circ} \mathrm{C}\right)$. Foi verificado que, em temperaturas elevadas, as amostras clinicas cresceram melhor que as ambientais. Para C. neoformans, tanto nos isolados ambientais como nos clinicos, em $24 \mathrm{~h}$ ou 48h, prevaleceu a produção moderada da enzima urease. Já no sétimo dia de leitura, houve produção significativa. O melhor tempo de leitura para visualização da produção de proteinase em ambos isolados e espécies foi no sétimo dia, sendo: $96 \%$ amostras clínicas e 94\% ambientais. Conclusão: São necessários novos estudos acerca da determinação dos fatores de virulência de $\mathrm{C}$. neoformans $e \mathrm{C}$. gattii isolados de liquor oriundos de pacientes com meningoencefalite e amostras ambientais em Sergipe, além de maior acuidade técnica e precisão estatística dos resultados.

Unitermos: Cryptococcus neoformans; proteínas fúngicas; micologia; leveduras; Cryptococcus gattii.

\section{REFERENCES}

1. CALLEJAS, A.; ORDONEZ, N.; RODRIGUES, M. C.; CASTANEDA, E. First isolation of Cryptococcus neoformans var. gattii serotype $\mathrm{C}$ from the environmental in Colombia. Med Mycol, v. 36, p. 314-44, 1998.

2. CASADEVALL, A.; PERFECT,J. R. Cryptococcus neoformans. American Society for Microbiology. Washington, 1998.
3. CASADEVALL, A.; BLANK, E. S.; CHEN, L. C. Extracellular proteinase activity of Cryptococcus neoformans. Clin Diagn Lab Immunol, v. 3, p. 570-4, 1996.

4. CASADEVALL,A; STEENBERG,J.N. The origin and maintenance of virulence for the human pathogen fungus Cryptococcus neoformans. Microbes and Infection, v. 5, p. 667-75, 2003.

5. CASADEVALLL, A.; ROSASA, B. A. L.; NOSANCHUKC, J. D. Melanin and virulence in Cryptococcus neoformans. Curr Opi Microbio, v. 3, p. 354-8, 2000. 
6. CHEN, L. C.; PIROFSKI, L. A.; CASADEVALL, A. Extracellular proteins of Cryptococcus neoformans and host antibody response. Infect Immun, v. 65, n.7, p. 2599-605, 1997.

7. DEL POETA, M.; LUBERTO, C.; GUILLOTE, A.; HENRY, J. Characterization of inositol phosphosphingolipid-phospholipase C1 (Isc1) in Cryptococcus neoformans reveals unique biochemical features. FEBS Lett, v. 585, p. 635-40, 2011.

8. DOS SANTOS, W. R. et al. Primary endemic Cryptococcosis gattii by molecular type VGII in the state of Para, Brazil. Mem Inst Oswaldo Cruz, v. 103, n. 8, p. 813-8, 2008.

9. ELLIS, D. H.; PFEIFFER, T. J.; Ecology, life cycle and infectious propagule of Cryptococcus neoformans. Lancet, v. 36, p. 923-5, 1990.

10. FORTES, S. T.; LAZÉRA, M. S.; NISHIKAWA, M. M.; MACEDO, R. C. L.; WANKE, B. First isolation of Cryptococcus neoformans var. gattii from a native jungle tree in the Brazilian Amazon rainforest. Mycoses, v. 44, p. 137-40, 2001.

11. HSHUE, P. R.; WU, H. C.; LIAW, S. J. Microbiological characteristics of clinical isolates of Cryptococcus neoformans in Taiwan: serotypes, mating types, molecular types, virulence factors, and antifungal susceptibility. Clin Microbiol Infect, v. 16, p. 696703, 2010.

12. TORRES-RODRÍGUEZ, J. M.; ALVARADO-RAMÍREZ, E.; GUTIÉRREZ-GALLEGO, R. Diferencias en la actividad de la enzima ureasa entre Cryptococcus neoformans y Cryptococcus gattii. Rev Iberoam Micol, v. 25, p. 27-31, 2008.

13. KIDD, S. E. et al. A rare genotype of Cryptococcus gattii caused the cryptococcosis outbreak on Vancouver Island (British Columbia, Canada). Proc Natl Acad Sci USA, v. 101, n. 49, p. 17258-63, 2004.

14. KWON-CHUNG, K. J.; VARMA, A. Do major species concepts support one, two or more species within Cryptococcus neoformans? FEMS Yeast Res, v. 6, n. 4, p. 574-87, 2006.

15. LAZÉRA, M.; PIRES, F. D. A.; CARNILO-COURA, L. Natural habitat of Cryptococcus neoformans var. neoformans in decaying wood forming hollows in living trees. J Med Vet Mycol, v. 34, p. 127-31, 1996.
16. LAZÉRA, M.; WANKE, B.; NISHIKAWA, M. M. Isolation of both varieties of Cryptococcus neoformans from saprophytic sources in the city of Rio de Janeiro, Brazil. J Med Vet Mycol, v. 31, p. 449-54, 1993.

17. LEVITZ, S. M.; BOEKHOUT, T. Cryptococcus: the once-sleeping giant is fully awake. FEMS Yeast Res, v. 6, n. 4, p. 461-2, 2006.

18. MATSUMOTO, M. T.; FUSCO-ALMEIDA, A. M.; BAEZA, L. C.; MELHEM MDE, S.; MEDES-GIANNINI, M. J. Genotyping, serotyping and determination of mating-type of Cryptococcus neoformans clinical isolates from Sao Paulo State, Brazil. Rev Inst Med Trop Sao Paulo, v. 49, n. 1, p. 41-7, 2007.

19. MILLER, G. W.; PADHYE, A. A.; BONN, W. V.; MARY. E. J.; BRANDT, E.; RIDGWAY, S. H.; Cryptococcosis in a bottlenose dolphin (Tursiops truncatus) caused by Cryptococcus neoformans var. gattii. JClin Microb, v. 40, p. 721-4, 2002.

20. MITCHELL, T. G.; PERFECT, J. R. Cryptococcosis in the era of AIDS- 100 years after the discovery of Cryptococcus neoformans. Clin Microbio Revi, v. 8, p. 515-48, 1995.

21. PERFECT, J. R.; CASADEVALL, A.; COLE, A.; MUKHERJEE, G. T.; COX, G. M. Urease as a virulence factor in experimental cryptococcosis. Infect Immun, v. 68, p. 443-8, 2000.

22. POWDERLY, W. G. Recent advances in the management of cryptococcal meningitis in patients with AIDS. Clin Infect Dise, v. 22, n. 2, p. 119-23, 1996.

23. SORRELL, TC; STEPHEN, C.; LESTER, S.; BLACK, W.; FYFE, M.; RAVERTY, S. Cryptococcus neoformans variety gatti multispecies outbreak of cryptococcosis on southern Vancouver Island, British Columbia. Med Mycol, v. 39, p. 155-168, 2002.

24. SOUZA, J. V. et al. Characterization of clinical isolates of the Cryptococcus neoformans-Cryptococcus gattii species complex from the Amazonas State in Brazil. Rev Iberoam Micol, v. 29, n. 1, p. 40-3, 2012.

25. TRILLES, L. et al. Regional pattern of the molecular types of Cryptococcus neoformans and Cryptococcus gattii in Brazil. Mem Inst Oswaldo Cruz, v. 103, n. 5, p. 455-62, 2008.

26. ZUYDERDUYN, S.; LIAN, T.; STEEN, B. R. Cryptococcus neoformans temperature-regulated transcription in the pathogenic fungus. Genome Res, v. 12, p. 1386-1400, 2002.

\section{MAILING ADDRESS}

